\title{
Respons Kedelai Edamame Terhadap Berbagai Jarak Tanam dan Dosis Pupuk Kotoran Ayam
}

\author{
${ }^{* 1}$ Budiyati Ichwan, ${ }^{1}$ Ridwan M., ${ }^{1}$ Eliyanti, ${ }^{1}$ Irianto dan ${ }^{2}$ Cici Pebria \\ ${ }^{1}$ Jurusan Agroekoteknologi Fakultas Pertanian, Universitas Jambi \\ ${ }^{2}$ Alumni Jurusan Agroekoteknologi Fakultas Pertanian Universitas Jambi \\ Jl. Raya Jambi - Ma. Bulian Km 15 Kampus Pinang Masak, Mendalo Darat Jambi 36361 \\ ${ }^{* 1}$ e-mail korespondensi : budiyati_ichwan@unja.ac.id
}

\begin{abstract}
Efforts to increase edamame production and productivity include regulating plant populations and increasing soil fertility. The aim of the study was to examine the response of edamame soybeans to various spacings and doses of chicken manure. The study aimed to examine the response of edamame soybeans to various spacings and doses of chicken manure. The experiment used a Randomized Block Design (RBD) with two factors, namely plant spacing which included: $30 \mathrm{~cm} x 10 \mathrm{~cm} ; 30 \mathrm{~cm}$ $x 20 \mathrm{~cm} ; 30 \mathrm{~cm} \times 30 \mathrm{~cm}$, and the dose of chicken manure fertilizer is: 5 tons ha-1; 10 tons ha-1, and 20 tons ha-1. Plant spacing and dose of chicken manure did not significantly affect, but each factor affected the number of branches, as well as the number and fresh weight of edamame pods. Edamame gave the best response at a spacing of $30 \mathrm{~cm} x 20 \mathrm{~cm}$ and a dose of chicken manure 15 tons ha-1. Edamame productivity from this study was only able to meet $48-50 \%$ of the productivity target for exports.
\end{abstract}

Keywords: Glyvcine max, organic matter, population, productivity

\begin{abstract}
Abstrak. Pengaturan populasi tanaman dan peningkatan kesuburan tanah merupakan upaya untuk meningkatkan produksi dan produktivitas edamame. Tujuan penelitian adalah mengkaji respons kedelai edamame terhadap berbagai jarak tanam dan dosis kotoran ayam. Percobaan menggunakan Rancangan Acak Kelompok (RAK) dengan 2 faktor, yaitu jarak tanam yang meliputi: $30 \mathrm{~cm} \times 10 \mathrm{~cm} ; 30 \mathrm{~cm}$ x $20 \mathrm{~cm} ; 30 \mathrm{~cm}$ x $30 \mathrm{~cm}$, dan dosis pupuk kotoran ayam yaitu : $5 \mathrm{ton} \cdot \mathrm{ha}^{-1} ; 10$ ton $\cdot \mathrm{ha}^{-1}$, dan $20 \mathrm{ton} \cdot \mathrm{ha}^{-1}$. Jarak tanam dan dosis kotoran ayam tidak berpengaruh nyata, namun setiap faktor berpengaruh terhadap jumlah cabang, serta jumlah dan bobot segar polong edamame. Edamame memberikan respons terbaik pada jarak tanam $30 \mathrm{~cm} \times 20 \mathrm{~cm}$ dan pada dosis kotoran ayam 15 ton $\cdot$ ha $^{-1}$. Produktivitas edamame dari penelitian ini baru mampu memenuhi 48 - 50\% dari target produktivitas untuk ekspor.
\end{abstract}

Kata kunci: bahan organik, Glycine max, populasi, produktivitas.

\section{PENDAHULUAN}

Kedelai edamame (Glycine max L. Merr.) adalah jenis kedelai yang dikonsumsi untuk sayuran (vegetable soybean) atau green soybean. Kedelai edamame merupakan kedelai yang dipanen dalam keadaan masih segar, dan dikonsumsi dalam bentuk polong muda. Biji edamame memiliki ukuran yang sangat besar lebih dari $300 \mathrm{~g}$ per 100 biji. Produksi kedelai edamame dapat mencapai $10-12$ ton $\cdot \mathrm{ha}^{-1}$, lebih besar dari kedelai biasa yang hanya berkisar 1,5 ton - 3 ton $\cdot$ ha $^{-1}$ (Setkab RI, 2014). Disamping itu karena dipanen muda (68-70 Hari Setelah Tanam/HST), maka umur produksinya menjadi lebih singkat, sehingga intensitas penanamannya lebih tinggi. Oleh sebab itu pengusahaan kedelai edamame menjadi lebih menarik, terutama sebagai komoditas untuk diekspor, mengingat kebutuhan berbagai negara terutama Jepang yang sangat tinggi terhadap kedelai edamame ini, serta harga dipasar ekspor yang cukup tinggi kurang lebih 1,9 USD per kg.

Kandungan gizi edamame cukup tinggi sehingga dapat dijadikan alternatif untuk pemenuhan gizi. Edamame mengandung asam lemak omega-3 dan omega-6 masing-masing sebesar $361 \mathrm{mg}$, dan $1794 \mathrm{mg}$ dalam 100 g-nya. Edamame juga kaya akan vitamin, mineral seperti mangan, fosfor dan $\mathrm{K}$, serta protein, serat makanan, dan mikronutrien terutama folat (Sudiarti, 2017).

Produksi kedelai edamame sejak tahun 2017 ditargetkan sebesar 9 ton $\cdot \mathrm{ha}^{-1}$ polong basah dalam upaya peningkatan untuk ekspor. Produksi edamame dapat ditingkatkan dengan memperluas areal penanaman, dan meningkatkan populasi tanaman per hektar, yang masih diperlukan informasinya terkait perbedaan wilayah dan musim yang ada di Indonesia (Balitkabi, 2018).

Peningkatan populasi tanaman dengan pengaturan jarak tanam dapat mempengaruhi luas daun, bobot kering tanaman, dan sistem perakaran tanaman. Pengaturan jarak tanam menyebabkan terjadinya persaingan unsur hara diantara tanaman bila jarak tanam yang digunakan terlalu sempit terutama untuk tanah-tanah miskin unsur hara atau lahan marginal seperti Ultisol.

Upaya untuk meningkatkan kesuburan tanah dan menurunkan tingkat persaingan yang timbul dengan meningkatnya populasi tanaman dapat dilakukan dengan penambahan bahan organik tanah seperti kotoran ayam. Namun bila jarak tanaman yang digunakan terlalu lebar dapat menurunkan hasil sejalan dengan berkurangnya jumlah tanaman per satuan luas serta menurunkan efisiensi pemanfaatan kotoran ayam yang diberikan. 
Pupuk kandang ayam dan jarak tanam dapat meningkatkan pertumbuhan dan produksi krokot belanda. Dosis 10 ton ha $^{-1}$ dan jarak tanam $3 \mathrm{~cm} \times 5 \mathrm{~cm}$ meningkatkan pertumbuhan daun dan memberikan bobot kering tertinggi (Uko et al., 2013). Luas dan bobot daun, serta bobot kering total tanaman dan jumlah polong rata-rata tertinggi kedelai didapat pada jarak tanam 30cm x 20cm (Tamura et al., 2017). Selanjutnya hasil penelitian Sitinjak dan Purba (2018), menunjukkan bahwa aplikasi kotoran ayam dan jarak tanam dapat meningkatkan hasil kacang hijau. Dosis 7,5 ton $\cdot \mathrm{ha}^{-1}$ dan jarak tanam $20 \mathrm{~cm}$ x $40 \mathrm{~cm}$ memberikan hasil tertinggi pada kacang hijau.

Informasi tentang jarak tanam dan dosis kotoran ayam yang tepat dalam pengusahaan edamame terutama di lahan marginal yang ketersediaannya cukup luas di Indonesia masih terbatas. Oleh sebab itu dalam upaya meningkatkan produktivitas edamame perlu dilakukan suatu penelitian untuk mengkaji respons kedelai edamame terhadap berbagai jarak tanam dan dosis kotoran ayam.

\section{METODE PENELITIAN}

Penelitian ini dilaksanakan di Teaching and Research Farm, Fakultas Pertanian Universitas Jambi. Penelitian disusun secara faktorial dengan Rancangan Acak Kelompok (RAK) dan tiga ulangan. Faktor pertama adalah jarak tanaman meliputi: $30 \mathrm{~cm} \times 10 \mathrm{~cm} ; 30 \mathrm{~cm} \times 20 \mathrm{~cm}$; dan $30 \mathrm{~cm} \times 30 \mathrm{~cm}$, sedangkan faktor kedua adalah dosis kotoran ayam yang terdiri dari 5 ton $\cdot$ ha $^{-1} ; 10$ ton $\cdot$ ha $^{-1}$; dan 15 ton $\cdot$ ha $^{-1}$.

Lahan tempat percobaan ditabur dengan pupuk kotoran ayam secara merata sesuai dengan dosis yang dicobakan satu minggu sebelum tanam. Benih kedelai edamame (varietas Ryoko) ditanam pada lubang yang telah disediakan dan ditanam dengan jarak sesuai dengan perlakuan. Pemupukan diberikan umur 14 Hari Setelah Tanam (HST) menggunakan Urea $50 \mathrm{~kg} \cdot \mathrm{ha}^{-1}$, SP36 $75 \mathrm{~kg} \cdot \mathrm{ha}^{-1}$, dan $\mathrm{KCl} 60 \mathrm{~kg} \cdot \mathrm{ha}^{-1}$. Edamame dipanen saat polong mudanya berwarna hijau segar (bernas dan belum menguning) yaitu umur 9 MST.

Pengamatan tanaman meliputi tinggi tanaman, diameter batang, jumlah cabang utama dan bunga, jumlah polong total dan berisi, serta bobot polong segar per hektar. Analisis data menggunakan Anova dan Duncan Multiple Range Test.

\section{HASIL DAN PEMBAHASAN}

Semua parameter yang diamati tidak dipengaruhi secara nyata oleh interaksi jarak tanam dan dosis kotoran ayam. Namun demikian diameter batang, jumlah cabang utama, jumlah polong total dan berisi, dan bobot polong segar edamame dipengaruhi oleh jarak tanam dan oleh dosis kotoran ayam.

Berbagai jarak tanam dan dosis kotoran ayam berpengaruh terhadap diameter batang edamame umur 7 MST. Jarak tanam $30 \mathrm{~cm}$ x $20 \mathrm{~cm}$ dan dosis kotoran ayam 15 ton $\cdot \mathrm{ha}^{-1}$ memberikan diameter batang tertinggi pada kedelai edamame (Tabel 1).

Tabel 1. Diameter batang kedelai edamame pada berbagai jarak tanam dan dosis pupuk $\quad$ kotoran ayam 7 MST Perlakuan Diameter batang $(\mathrm{mm})$

Jarak tanam $(\mathrm{cm} \mathrm{x} \mathrm{cm)}$

$30 \times 10 \quad 6,21 \mathrm{~b}$

$30 \times 20 \quad 8,02 \mathrm{a}$

$30 \times 30 \quad 5,91 \mathrm{~b}$

Pupuk kotoran ayam (ton $\left.\cdot \mathrm{ha}^{-1}\right)$

5

$10 \quad 6,94 \mathrm{a}$

$15 \quad 7,42 \mathrm{a}$

Keterangan: Huruf kecil yang sama setelah angka tidak berbeda nyata menurut Duncan Multiple Range Test taraf $5 \%$.

Jumlah cabang kedelai edamame dipengaruhi oleh berbagai jarak tanam dan berbagai dosis kotoran ayam. Jarak tanam $30 \mathrm{~cm}$ x $20 \mathrm{~cm}$ dan pupuk kotoran ayam 15 ton $\cdot \mathrm{ha}^{-1}$ memberikan cabang terbanyak pada kedelai edamame umur 7 MST. 
Budiyati Ichwan, Ridwan M., Eliyanti, Irianto dan Cici Pebria. Respons Kedelai Edamame Terhadap Berbagai Jarak Tanam dan Dosis Pupuk Kotoran Ayam

Tabel 2. Jumlah cabang utama kedelai edamame pada berbagai jarak tanam dan dosis kotoran ayam umur 7 MST.

\begin{tabular}{cc}
\hline Perlakuan & Cabang utama \\
\hline Jarak tanam $(\mathrm{cm} \mathrm{cm})$ & $2,99 \mathrm{a}$ \\
$30 \times 10$ & $3,70 \mathrm{a}$ \\
$30 \times 20$ & $2,57 \mathrm{~b}$ \\
$30 \times 30$ & \\
Pupuk kotoran ayam $\left(\right.$ ton $\left.^{-h^{-1}}\right)$ & $2,55 \mathrm{~b}$ \\
5 & $2,78 \mathrm{~b}$ \\
10 & $3,60 \mathrm{a}$ \\
\hline
\end{tabular}

Keterangan: Huruf kecil yang sama setelah angka tidak berbeda nyata menurut uji Duncan Multiple Range Test taraf $5 \%$.

Jumlah polong total dan jumlah polong berisi kedelai edamame dipengaruhi secara nyata oleh berbagai jarak tanam dan berbagai dosis kotoran ayam yang diperlakukan. Berbagai jarak tanam dan dosis pupuk kotoran ayam memberikan jumlah polong total dan berisi yang berbeda (Tabel 3).

Tabel 3. Jumlah polong total dan berisi kedelai edamame pada berbagai jarak tanam dan dosis kotoran ayam pada saat panen

\begin{tabular}{ccc}
\hline Perlakuan & Polong total (buah) & Polong berisi (buah) \\
\hline Jarak tanam $(\mathrm{cm})$ & & \\
$30 \times 10$ & $34,57 \mathrm{~b}$ & $20,04 \mathrm{~b}$ \\
$30 \times 20$ & $36,16 \mathrm{a}$ & $20,99 \mathrm{a}$ \\
$30 \times 30$ & $34,10 \mathrm{~b}$ & $19,53 \mathrm{~b}$ \\
Pupuk kotoran ayam (ton $\left.\cdot \mathrm{ha}^{-1}\right)$ & $34,02 \mathrm{~b}$ & $19,41 \mathrm{c}$ \\
5 & $34,76 \mathrm{~b}$ & $20,19 \mathrm{~b}$ \\
10 & $35,87 \mathrm{a}$ & $20,96 \mathrm{a}$ \\
\hline
\end{tabular}

Keterangan: : Huruf kecil yang sama setelah angka tidak berbeda nyata menurut uji Duncan Multiple Range Test taraf $5 \%$.

Bobot polong segar edamame dipengaruhi masing-masing oleh jarak tanam dan dosis kotoran ayam. Jarak tanam sempit menghasilkan bobot polong segar edamame yang lebih tinggi, sementara itu dosis kotoran ayam sampai 15 tonha $^{-1}$ masih meningkatkan hasil edamame (Tabel 4).

Tabel 4. Bobot polong segar edamame pada berbagai jarak tanam dan dosis pupuk kotoran ayam

\begin{tabular}{cc}
\hline Perlakuan & Bobot polong segar $\left(\right.$ tonha $\left.^{-1}\right)$ \\
\hline Jarak tanam $(\mathrm{cm} \mathrm{x} \mathrm{cm)}$ & $3,91 \mathrm{a}$ \\
$30 \times 10$ & $4,31 \mathrm{a}$ \\
$30 \times 20$ & $1,85 \mathrm{~b}$ \\
$30 \times 30$ & $2,80 \mathrm{~b}$ \\
Pupuk kotoran ayam $\left(\right.$ ton $\cdot$ ha $\left.^{-1}\right)$ & $2,84 \mathrm{~b}$ \\
5 & $4,44 \mathrm{a}$ \\
10 & \\
\hline
\end{tabular}

Keterangan: : Huruf kecil yang sama setelah angka tidak berbeda nyata menurut uji Duncan Multiple Range Test taraf $5 \%$.

Bila dilihat respons edamame terhadap berbagai dosis kotoran ayam yang diberikan, semakin tinggi dosis kotoran ayam akan semakin meningkatkan pertumbuhan dan hasil, bahkan sampai dosis 15 ton.ha ${ }^{-1}$ masih terus meningkat atau dapat dikatakan bahwa pola yang dihasilkan masih bersifat linear (Gambar 1). 


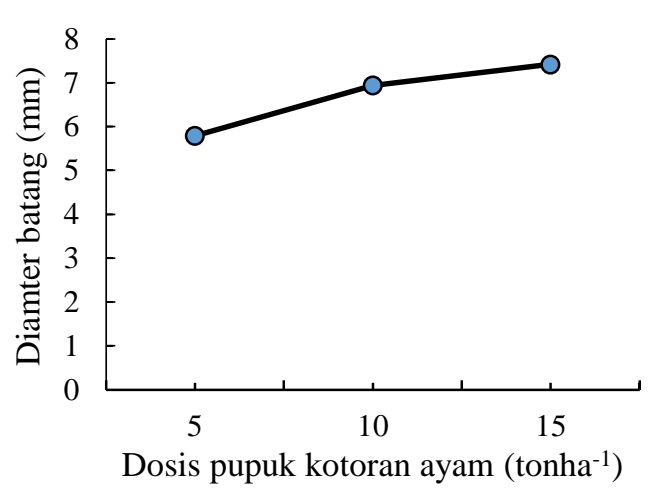

(a)

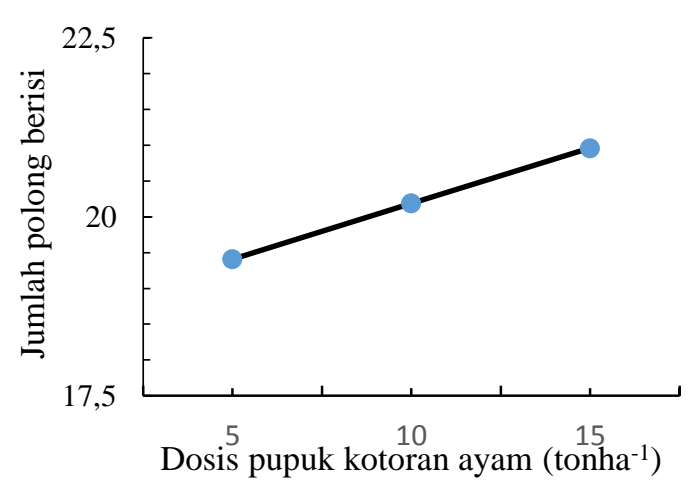

(c)

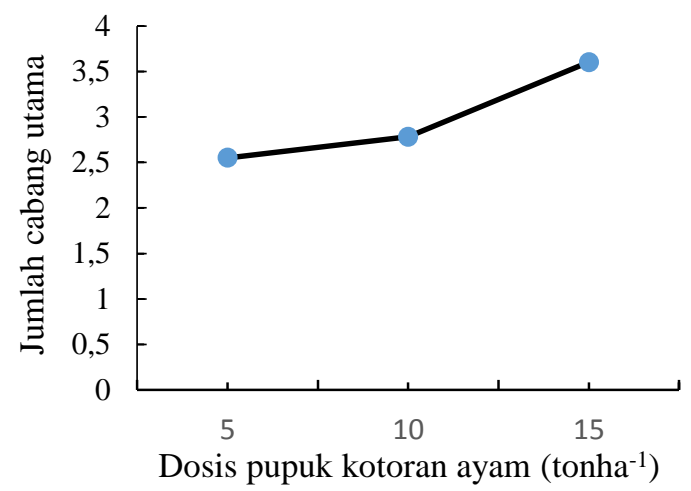

(b)

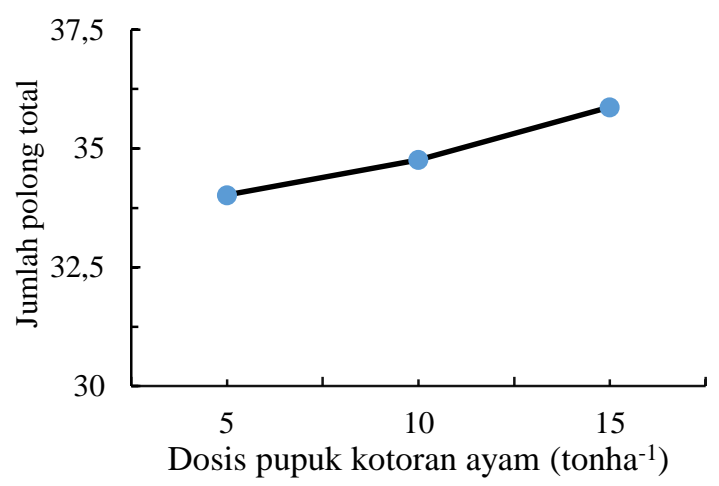

(d)

Gambar 1. Pertumbuhan dan hasil edamame pada berbagai dosis pupuk kotoran ayam.

Pengaturan populasi tanaman dan pemberian pupuk kotoran ayam tidak menunjukkan interaksi yang nyata pada kedelai edamame, namun secara tunggal berpengaruh nyata. Peningkatan populasi tanaman dengan memperkecil jarak tanam dengan jarak $30 \mathrm{~cm} \times 10 \mathrm{~cm}$ memberikan pertumbuhan dan hasil edamame yang lebih rendah dari jarak tanam $30 \mathrm{~cm} \times 20 \mathrm{~cm}$. Walaupun strategi peningkatan populasi tanaman merupakan strategi peningkatan hasil tanaman, namun pada kenyataannya peningkatan populasi tanaman justru menurunkan pertumbuhan dan hasilnya. Giridhar et al. (2020) kepadatan populasi tanaman merupakan faktor kunci yang mempengaruhi pertumbuhan dan hasil panen, namun kepadatan populasi yang tinggi dapat mempengaruhi intersepsi cahaya, serapan hara dan ketersediaan air tanaman. Hasil penelitian pada tanaman jagung menunjukkan bahwa kepadatan tanam yang tinggi menaungi tajuk tanaman, mengurangi transmisi cahaya dalam suatu populasi dan mempercepat penuaan daun, yang semuanya mempengaruhi fotosintesis jagung, akumulasi dan distribusi fotosintat, serta membatasi perkembangan biji (Li et al., 2019).

Penggunaan jarak tanam yang lebar ternyata tidak mampu meningkatkan pertumbuhan dan hasil edamame. Respons kedelai edamame pada jarak tanam $30 \mathrm{~cm} \times 10 \mathrm{~cm}$ dan $30 \mathrm{~cm} \times 20 \mathrm{~cm}$ lebih baik dari jarak tanam $30 \mathrm{~cm} \times$ $30 \mathrm{~cm}$. Salah satu tujuan pengaturan jarak tanam adalah mengurangi kemunculan gulma di areal pertanaman, namun bila terlalu lebar justru akan meningkatkan jumla gulma yang tumbuh, sehingga menimbulkan persaingan antara tanaman dan gulma dalam memperebutkan faktor-faktor untuk pertumbuhan tanaman, yang pada akhirnya dapat menurunkan pertumbuhan dan hasil tanaman (Mardiyana,2009). Hasil penelitian yang dilakukan oleh Vera dkk. (2020) pada tanaman kacang tanah menunjukkan bahwa jarak tanam yang lebih lebar yaitu $40 \mathrm{~cm} \times 30 \mathrm{~cm}$ menghasilkan populasi gulma yang lebih banyak dan bobot gulma yang lebih tinggi dibandingkan dengan jarak tanam yang lebih sempit $40 \mathrm{~cm}$ x $20 \mathrm{~cm}$. Selanjutnya hasil penelitian Nugraha dkk. (2021) menunjukkan bahwa jarak tanam yang lebih lebar $(20 \mathrm{~cm} \times 20 \mathrm{~cm})$ pada bawang merah memberikan bobot kering gulma yang lebih tinggi dibandingkan dengan jarak tanam sempit $(15 \mathrm{~cm}$ x $20 \mathrm{~cm}$ dan $15 \mathrm{~cm}$ x $15 \mathrm{~cm})$ pada 30 hari setelah olah tanah.

Jarak tanam ideal untuk edamame dari hasil penelitian ini adalah $30 \mathrm{cmx} 20 \mathrm{~cm}$, dimana pada jarak tanam ini tidak terjadi kompetisi antar tanaman, dan tidak saling menaungi sehingga dapat tumbuh lebih baik dan memberikan hasil yang tinggi. Jarak tanam $30 \mathrm{~cm}$ x $20 \mathrm{~cm}$ memberikan diameter, jumlah cabang, serta jumlah dan bobot segar polong yang lebih tinggi dari jarak tanam lainnya. Namun demikian bobot segar yang didapat dengan jarak tanam 30 $\mathrm{cm} \times 20 \mathrm{~cm}$ sebesar 4,3 tonha ${ }^{-1}$ masih lebih kecil dibandingkan dengan potensi hasil edamame sebesar 10 - 12 tonha $^{-1}$ dengan jarak tanam $20 \mathrm{~cm}$ x $20 \mathrm{~cm}$ (Setkab RI, 2014; Soewanto dkk., 2016). Populasi tanaman yang berkurang dengan semakin lebarnya jarak tanam yang digunakan juga menyebabkan hasil yang diperoleh dalam penelitian ini menjadi lebih rendah. Menurut Giridhar et al. (2020) kepadatan populasi yang optimal untuk berbagai varietas 
tanaman perlu ditentukan di zona agroklimat dan tanah yang berbeda jenis untuk meningkatkan produktivitas tanaman.

Pemberian pupuk kotoran ayam 15 tonha $^{-1}$ menghasilkan diameter batang, jumlah cabang, dan polong total serta polong berisi edamame tertinggi. Menurut Adekiya et al., (2019) dan (García-Orenes et al., 2016) pemberian bahan organik seperti kotoran ayam bertujuan memperbaiki sifat fisik dan biologi tanah. Hasil penelitian Dikinya dan Mufwanzala (2010) menunjukkan bahwa pemberian kotoran ayam pada tanah yang ditanami dengan bayam memberikan pengaruh yang positif dalam meningkatkan kesuburan tanah, meningkatkan kandungan $\mathrm{N}, \mathrm{P}$ tanah, serta basa yang dapat dipertukarkan. Selanjutnya Pangaribuan et al. (2020) menyatakan bahwa pemberian kompos kotoran ayam meningkatkan aktivitas mikrobia tanah pada lahan yang ditanami dengan jagung manis. Pemberian pupuk kotoran ayam pada pertanaman edamame diduga dapat memperbaiki kesuburan tanah sehingga mampu meningkatkan pertumbuhan dan hasil edamame.

Azmi et al., (2019) menyatakan bahwa pupuk kandang ayam sebesar 10\% (V/V) meningkatkan jumlah cabang, jumlah daun, dan jumlah buah tanaman Ficus caria (buah tin). Selanjutnya Perkasa et al. (2016) menyatakan bahwa pemberian pupuk kandang ayam $1000 \mathrm{~g}$ per $8 \mathrm{~kg}$ tanah pada tanaman daun dewa menghasilkan tinggi tanaman dan diameter kanopi yang lebih tinggi dari $500 \mathrm{~g}$ dan tanpa pupuk kandang ayam.

Berdasarkan hasil analisis BPTP Jambi (2020), pupuk kotoran ayam yang digunakan dalam penelitian ini mengandung $\mathrm{N}$ total $2.07 \%$, P total $1.34 \%$, dan $\mathrm{K}$ total $0.74 \%$. Kadar unsur hara yang dikandung kotoran ayam ini merupakan kadar unsur hara kotoran ayam pada umumnya yang berkisar antara N $1.5-3.12 \%$; P 1.3 - 1.92\%; dan K 0.8-1.2\% (Lingga, 1991; dan Zainal dkk., 2013). Walaupun kandungan haranya dalam kisaran cukup baik, namun hasil edamame yang diperoleh dalam bentuk bobot segar polong sebesar 4,4 tonha ${ }^{-1}$ masih rendah dibandingkan dengan potensi hasilnya, maupun dari target produksi bobot polong segar edamame sebesar 9 tonha $^{-1}$ (Balitkabi, 2018).

Soewanto dkk. (2016) menyatakan bahwa untuk mendapatkan pertumbuhan dan hasil edamame yang tinggi, diperlukan pupuk kandang sebesar 10 tonha $^{-1}$ sampai 20 tonha $^{-1}$, dan kebutuhan ini semakin meningkat bila edamame diusahakan di lahan marginal yang kesuburannya rendah seperti Ultisol. Hal ini sejalan dengan hasil penelitian yang dilakukan oleh Purba dkk. (2018), dimana hasil tertinggi edamame dalam bentuk jumlah polong didapat pada pupuk kandang sapi sebesar 30 tonha $^{-1}$. Dalam upaya meningkatkan hasil edamame perlu kiranya mempertahankan jarak dalam barisan tanaman berdasarkan hasil penelitian ini, dan mempersempit jarak antar barisan tanaman, serta meningkatkan dosis kotoran ayam yang digunakan. Pengaruh interaksi yang tidak nyata dengan pengaturan jarak tanam dan dosis pupuk kotoran ayam diduga disebabkan oleh rendahnya dosis kotoran ayam yang dicobakan. Peningkatan dosis pupuk kotoran ayam lebih dari 15 tonha $^{-1}$ (hasilnya yang masih bersifat linear) dan peningkatan kualitas dengan mengkomposkannya menggunakan mikroorganisme seperti trichoderma diharapkan dapat meningkatkan hasil edamame.

\section{KESIMPULAN}

Kedelai edamame belum menunjukkan respons yang positif terhadap berbagai jarak tanam dan dosis kotoran ayam yang diberikan. Peningkatan populasi edamame dengan mempersempit jarak tanam hanya mampu meningkatkan pertumbuhan dan hasil edamame pada $30 \mathrm{~cm}$ x $20 \mathrm{~cm}$, sedangkan respons edamame terhadap pemberian pupuk kotoran ayam masih bersifat linear. Jarak tanam $30 \mathrm{~cm}$ x $20 \mathrm{~cm}$ menghasilkan bobot polong segar 4,3 ton $\cdot \mathrm{ha}^{-1}$, sementara itu dosis pupuk kotoran ayam 15 tonha $^{-1}$ menghasilkan bobot polong segar edamame sebesar 4,4 tonha $^{-1}$.

\section{DAFTAR PUSTAKA}

Adekiya, A. O., T. M. Agbede, C. M. Aboyeji, O. Dunsin, and V. T. Simeon. 2019. Effects of biochar and poultry manure on soil characteristics and the yield of radish. Scientia Horticulturae 243 : 457-463.

Azmi, F. M., N.S. Tajudin, R. Shahari, and Che N.A. Che Amri. 2019. Effect of different chicken manure rates of on early growth of fig (Ficus carica). Environmental Contaminants Reviews 2(1):19-22.

Balitkabi. 2018. Kedelai sayur edamame. http:balitkabi.libang.pertanian.go.id (diakses maret 2021).

Dikinya, O., and N. Mufwanzala. $2010 . \quad$ Chicken manure-enhanced soil
fertility and productivity: Effects of application rates. Journal of Soil Science and Environmental Management 1(3): 46-54.

García-Orenes, F., A. Roldán, A. Morugán-Coronado, C. Linares, A. Cerdà, and F. Caravaca. 2016. Organic fertilization in traditional mediteranean grapevine orchards mediates changes in soil microbial community structure and enhances soil fertility. Land Degradation and Development 27(6): 1622-1628.

Giridhar, K., P.S.Raju, G.Pushpalatha, and C. Patra. 2020. Effect of plant density on yield parameters of cowpea (Vigna unguiculata L.). International Journal of Chemical Studies 8(4):344-347. 
Li, R, P. Liu, S. Dong, J. Zhang, and B. Zhao. 2019. Increased maize plant population induced leaf senescence, suppressed root growth, nitrogen uptake, and grain yield. Agronomy Journal 111 (4): 1581-1591.

Mardiyana, N. 2009. Pengaruh pengaturan jarak tanam pada pertumbuhan dan hasil tanaman talas (Colocasia esculenta L. Schoot.) varietas Antiquorum. J. Produksi Tanaman 2(3) : 11 -14.

Nugraha, A.S., J. Mutakin, dan N. Sativa. Pengaruh berbagai pupuk kandang dan jarak tanam terhadap keanekaragaman, dominansi dan laju tumbuh gulma pada tanaman bawang merah (Allium ascalonicum L.). JAGROS 5 (2): 353-362.

Pangaribuan, D. H., Sarno, Y.Liliana, and S. Bahriana. 2020. Effect of chicken compost and KCl fertilizer on growth, yield, post-harvet quality of sweet corn and soil health. Agrivita 42(19):131-142.

Purba, J. H., I.P.parmila, dan K.K. Sari. 2018. Pengaruh pupuk kandang sapi dan jarak tanam terhadap pertumbuhan dan hasil kedelai (Glycine max L. Merrill) varietas edamame. Agro Bali (agricultural Journal) 1(2): 69-81.

Setkab RI. 2014. Kedelai Jember Tembus Pasar Internasional. https:/setkab.go.id/kedelai-jember-tembus-pasarinternasional (diakse Maret 2021).

Soewanto, H., A. Prasongko, dan Sumarno. 2016. Agribisnis edamame untuk ekspor dalam Kedelai, Teknik Produksi dan Pengembangan. http://balitkabi.litbang.pertanian.go.id (diakses 25 September 2021).

Sitinjak, L., dan E. Purba. 2018. Response to growth and production of green beans (Vigna radiate L.) in various cropping spots and fertilizer provision of layer chickens. International Conference on Agriculture, Environment, and Food Security 122.

Sudarti, D 2017. The effectiveness of biofertilizer on plant growth soybean edamame (Glycine max L.) Jurnal SainHealth 1(2): 987-106

Tamura, P., R. Soelistyono, dan B. Guritno. 2017. Pengaruh jarak tanam dan pemberian dosis pupuk kandang ayam terhadap pertumbuhan dan hasil kedelai (Glycine max L.). Jurnal Produksi Tanaman 5(8):1329-1337.

Uko, A. E., I.A. Udo, and J.O. Shiyam. 2013. Effect of poultry manure and plant spacing on the growth and yield of waterleaf (Talinum fructicosum L.) Journal of Agronomy 12(3):146-152.

Vera, D. Y.S., E. Turmudi, dan E. Suprijono. 2020. Pengaruh jarak tanam dan frekuensi penyiangan terhadap pertumbuhan, hasil kacang tanah dan populasi gulma. Jurnal Ilmu-ilmu Pertanian 22(1): 16-22.

Zainal, M., A. Nugroho, dan N. E. Suminar. 2013. Respon pertumbuhan dan hasil kedelai pada berbgai tingkat pemupukan $\mathrm{N}$ dan pupuk kandang aya. Jurnal Produksi Tanaman 2 (6): 484-490. 